\title{
The Quest of Society and Marriage as Local and Global Context, the Syariah in Indonesia
}

\author{
Widjajanti M Santoso', Usman Syaroni ${ }^{2}$, Sri Sunarti Purwaningsih ${ }^{3}$ \\ ${ }^{1,2}$ Research Centre for Social and Culture, Indonesian Institute of Sciences, \\ ${ }^{3}$ Research Centre for Population, Indonesian Institute of Sciences \\ ${ }^{1}$ widjasantoso@gmail.com, ${ }^{2}$ asyqi_wahidi@yahoo.com, ${ }^{3}$ nartipurwa@gmail.com
}

\begin{abstract}
The implementation of sharia in business and economy makes great progress, however, in society, there are many doubts, such as in marriages. Globalization and the internet have produced a disruptive context where past habits and knowledge changed dramatically. This article shows the disruptive context, by using critics of society as a concept and use women and marriage as a case. The arguments are marriage is a local context, as well as global, the mobility of people, have made marriage accessible from people of different religions, and nationalities, however, the registering is problematic. The research uses 'controversial' marriage in terms of religiosity, on sirri marriage, its bat (registered marriage), contracted marriage, and marriage between people with different religions. All of these cases are 'controversial due to ineligibility to register that should be based on one religion and cases of people who resist the registering. This qualitative research finds out that marriage is a long-lasting debate and discourses that continues until now, the government has made that registering the marriage is an obligation after the marriage process in front of the religion. Marriage has changed from societal norms, a specific ritual with many symbols, to civil rights and duties. Only people with such a legitimate marriage process can claims protection under the law. Those who support polygamy, child marriage and sirri, use religious arguments, neglecting women's and children's interests. The result shows women as unprotected citizens due to polygamy, child marriage, and marriage between people with different religions. This is an agenda for the discourse of Sharia in the state and societal level that should be able to produce justice and belongings, to all citizens.
\end{abstract}

Keywords

Society, marriage, registered, controversial marriage, family law

Article Received: 10 August 2020, Revised: 25 October 2020, Accepted: 18 November 2020

\section{Introduction}

The $\operatorname{article}^{1}$ uses a general understanding of Shariah, like norms, rules based on Islamic principles [1]. In this term, shariah has a dynamic instead of static meaning, it shows variation instead of monolithic. Sociologically the dynamic of shariah is exposed by the madzab in Islamic thinking; in fikih or Islamic rules, there exist various ulama interpretations (qaul al-'ulama). Differences and even opposite interpretations exist, in everyday life, the individual might follow one interpretation that might be in opposition with others [2] [3] [4] [5] [6]. As a way to manage the society, sharia follow rules such as to conduct good deeds and society best interest

1 This article is a part a research of the Implementation of Shariah in Indonesia in Everyday Life Context funded by DIPA P2MB, 2016. The team consists of Usman, M Hisyam, Widjajanti M Santoso. Endang Turmudi, Dwi Purwoko. (kemashlahatan umat) or maqashid al-sharia'ah. As a dynamic reality in society, there are possibility individual chooses his or her interest over the debate on ikhtilafiyah furu'iyah, conflict on the element instead of a basic understanding of shariah.

As a context, this article uses research on the meaning of the everyday life of shariah in marriage, the basic oath of a treaty. In Indonesia's case, marriage has a close relation to ethnic differences and social change [7]. We use common tern such as controversial marriage to show a gap at the societal level. This is a different side of the discourse over shariah that usually in terms of law, politics, popularity, economy, and religious court [8] [9]. We also elevate the marriage subject to globalization and critics over the meaning of society [10]. Our article asks the position of women in marriage and its marginalization as a citizen, by using Urry's critical analysis, we hope to give new meaning to marriage as a part of the globalization effect. The 
first section is a critical view of the meaning society that we take as granted of its meaning, in spite it has various meanings. The second section is a description of marriage as a controversial issue in the Indonesia context, an everyday life social situation has resonance with the political. There more general terms are religious intermarriage, interreligious marriage, interfaith marriage, atau mixed marriage [11], contract marriage, its bat nikah (registering marriage) and sirri marriage due to traditions, polygamy and child marriage. In Indonesia's context, it becomes a controversial issue due to the normative male interest and legitimacy.

\section{Method}

This research uses interviews, FGD (Focus Group Discussion), and site visits, however, most of the cases are sensitive and only several women are interviewed. We also interviewed individuals that relate to this issue such as the penghulu in the marriage registry's office. We conduct 5 controversial marriage issues, sirri marriage, contract marriage, interreligious marriage, and its bat or registering the marriage [12]. The research uses the focus group discussion (FGD) talking about the type of marriage and the reasons behind the marriage. In the FGD, there are several important and resource able persons in the issue involved. There are one researcher in each issue and the researcher develops their field outreach. For example, the its bat use women approach to discussing the situation by depth interview of the 12 women, who had participated in a program to registered the marriage, in the village in the outskirt of Bogor. The program jointly process the its bat, from PKK (Pemberdayaan dan Kesejahteraan Keluarga), LIPI (Lembaga Ilmu Pengetahuan Indonesia) the KUA (Religious Registered Office), and the Pengadilan Agama (Religious Court)

\section{Marriage as Local and Global Context, a Reading Context}

Urry [10], critically decipher the meaning of society, due to the largest extent of mobility that brings out challenging context to considerate the meaning of society. There are three things that society is taken for granted as sociological context such is represented by the agency, institutions, world system; society represents the nation-states; globalization represents a challenging meaning to the society [10]. Globalization has change everything and made mobility as the mark of modern society. As an impact mobility has been possible also because the development of technology of transportation and communication, people perception, imagination, motivation and life change dramatically. In general society represent country or nation, and how is the change happened to the society as a concept and nation or country as the state. Therefore, Urry's laid question is whether the state could control the society in the national context considering the global has made some social relationship matter. Urry suggests viewing the meaning of social governmentality to rapid and diverse mobility. He examines the exemplary problem of borders, mobility, and governance [10].

The impact of globalization is an interesting issue, as Appadurai [13] describes by using media scapes, techno scapes, ethno scapes, finance scapes, and ideo scapes. This scape represents global networks and intricacies that influence society, in this matter the scapes produce globalnational networking of cultural economy. Interestingly, as Appadurai has describes important scapes, it makes sense in theoretical matters and tends to make the social change as happened generally. Urry, however, makes the global impact thoroughly by giving global impact to six cases such as its impact on metaphor, traveling, senses, times, dwelling, and citizenship. As a sociologist, Urry continues his argument to the making of the sociology of mobility and the existent of global civil society. Which the later would be anchoring the problem of marriages and the position of women in religious matters. The basic understanding of society lies in the rights and duties of the citizen, formerly to one's country, however there are things have meaning for the human being such as environment that should be seen as global citizen rights and duties to care. Urry states marriages is a bounded element that one view women and marriage belong the nationhood for many reasons from reproductive to the religion's normative of childbearers and child-rearers [10]. It makes women the least subject as state's citizenship regulatory. What Urry has to do with marriage, probably nothing, but for the issue of marriage, his three 
compelling subjects of borders, mobility, and governmentality are intriguing as concepts to put the marriage in different perspectives. According to his critical understanding of society, it relates to the states and nation-states, as borders to decimate whose people or citizens of that country. In this context, common identity becomes the glue over consideration of society. However, this bounded meaning of society is destabilized by globalization that produces social mobility in terms of geographical, image, knowledge, lifestyles. In this instance, the government has to change its attitude that Urry defines as gardening and gatekeeper. The gardening attitude would like to control, to regulate, and to order society, it develops the meaning of "good society". The gatekeeper, however, is making sure that citizen is protected, and able to keep the need of the society as a whole. The gatekeeper makes sense of the destabilizing effect of globalization that shows citizenship is important at the same time making sure that society is protected. The state makes sure that citizenship has its rights as well as living with the global norms and values such as put the environment as one of its important subjects of governmentality. The state grows toward gatekeepers instead of gardening.

This article uses citizenship and argues that Urry's sociological approach still lacking the problem of gender, or at least we can say that gender problematizes it. In this part, the contribution of the gender or women or feminist studies are giving a problematic less discussed, as not only women is rarely seen as subject of citizenship but also her problem trivialized. For women, the situation would be different, such as backlash as a worldwide phenomenon [14].

Globalization produces resentment, fear toward women backlashed the achievement of the women's moment. Backlash is the social phenomena where the achievement of women's movement are seen as detrimental to society such as viewing that feminism is against family [15], this attitude produces individual as well as institutional rules against women such as budgetcutting or not seeing women problem as the problem of the society.

In Urry's perspective, mobility is an important element and for citizenship matters, it consists of the rights and duties. Every citizen should be provided with both, is a common understanding of citizenship, but taken to case the social situation would produce a paradox. Marriage is a part of mobility as people travel, communicate also by the mediation of the computer and gadget, domestic labor is particularly a present global phenomenon. Probably due to women, it lost in the argument of mobility. Urry also attached citizenship with nationhood, where women and their marriage somehow is seen as a property of one (self) or nation. Therefore marriage is not solely a special for individuals but also for community and nationhood in general. Below, the article would describe the case in the everyday life situation and put marriage as a case of controversial seeing from the liability of the society.

\section{Result: Marriage as Privat and Law Matter}

Marriage is not a private matter, has been said above that there is some prerequisite to marriage such as the couple, the modin or ulama who legitimate to marry them, two persons as a witness and there is some announcement of the marriage. Ideally speaking, the witness is subject to marriage as a law matter, they will be consulted if there is a problem in the marriage. However, the witness is representing the law, have limitations if they die the law died with them. This is to show that registering the marriage is a strategic matter to support marriage in terms of law and protection. Marriage is a law-related to the community. Without these, in religious matter the marriage is illegitimate. The grey areas between legitimate and illegitimate, religious, or quasireligious are our findings. The other is, even though Indonesia's women have stated polygamy, child marriage as a social problem since 1928, in reality, it is mostly left out unnoticed as a problem [16]. Unfortunately, these problems raise at present time, questioning society and modernity.

In statistics, the problem related to the case of controversial marriage is undetected such as the number of divorce and the reasons to divorce from BPS (statistic bureau) data from Dirjen Badan Peradilan Agama or religious court 4 Maret 2019, there is 392.610 divorce case [17]. The reasons are

1. Zina 1470

2. Alcoholic 3468 
3. Drugs and narcotics 1171

4. Gambling 2163

5. Leaving the responsibility 71623

6. In jail 1064

7. Polygamy 1211

8. Domestic violence 8764

9. Disability 766

10. Continue in conflict 183085

11. Forced marriage 941

12. Heresy 869

13. Economy 110909

14. Others 5106

The Indonesia family law or UU Perkawinan No. $1 / 1974$, ps. 2 ayat 1 , legitimacy is important and has two important points, the first marriage is legitimate in front of religion and registering the marriage [18] [19]. The problem lies in these two points with a different side. Registering the marriage is one of several social policies concerning the administrasi kependudukkan population administration, as governance in administration getting better, so registered of birth, marriage for example became a requirement for everything, from getting to school to search for formal employment. A part of modernity means that everything has to be counted and registered, for some of Indonesia especially in the remote and rural areas, to registered steps of life such as birth, marriage is still considered as tradition and they have their way to manage rite de passage. Not to mention that they have to travel in some distance, to get into the office to register a marriage, in this case. There are consequences if we don't have a marriage certificate, we will have some difficulty having a birth certificate that only states mother's name without the father's name. As an effect, some institutions might be said that it is necessary to have both parents in the birth certificate. The marriage certificate is a requirement for pilgrimage and to have a passport.

The Siri marriage claim to have a religious marriage but unregistered their marriage, sirri means secrecy, which only limited people know about its existent. It is controversial as Islamic norms in marriage are several, and one of them is showing or making an announcement about the marriage is an obligation, other are not. In terms of marriage law, people unregistered their marriage are several causes, such as they only think in terms of religious matters. The other is the polygamous marriage, that people kept marriage as secret. To have a relationship outside the wedlock is zina that would cause them to go to hell, sirri marriage is a way out. Registering the marriage is supported by the religious institution and civil society such as Majelis Ulama Indonesia Provinsi DI Yogyakarta, PW NU Yogyakarta dan PW Muhammadiyah [12]. They support state regulation of the marriage registry to give women and children protection under the law especially civil rights. The family law states that couples could marriage for a certain age, 16 for females and 19 for males, the Undang-Undang No 16 Tahun 2019 to change the Undang-Undang Nomor 1 Tahun 1974 has risen the age to 19 for all male and female [20].

The sirri marriage use for several reasons [21], first is the child marriage, that due to the underage, parents, and the couple itself could not register their marriage. Second, the law said that the husband could have a second wife as long as he gets permission from his wedded wife, which is difficult. Therefore husband uses short cut to have a religious marriage to avoid zina and to hide his marriage toward his wedded wife. From the discussion, some couple uses sirri marriage due to separation of them for education in a different city. Later on, when they already pass the education they could marry in the registered office, or registering their marriage. In society, the resistance over registering the marriage especially for people who uses religious arguments is increasing. The case of popular ulama that married their children under age, or people who promote child marriage exposed in the media and even become a trend in itself.

The case of the its bat is closely related to the sirri marriage. We went to the village several years before becoming the site to manage the program of its bat as a part of participatory research. The women in the village stated that their marriage is unregistered and they have wanted to register, but they don't know the process[22] [23]. Therefore a part of the participatory research, we jointly in managing and financing by asking the office of registered marriage which then contacts the religious court. We have managed two its bat programs before the budget-cutting [24]. The couple who had listed for its bat have to show their marriage in monogamy, and the office makes 
sure there is no related problem to the law, such as have offspring from a previous marriage. The child marriage in the village is a common phenomenon, they usually say for reasons to avoid teen pregnancy and zina [25]. For girls there are reasons for not continuing their study, they get embarrassed because they find out all girls had left the school. It is a part of the reasons that the school is quite far away from their village. It is a general commentary that it is slightly useless for girls to continue education, eventually, they will marry and become housewives or mothers. A small part is forced marriage, which will last for months or only for several years, and then they remarried for second, third or until they find out suitable husband. The its bat itself is a part of KHI - Compilation of Islamic Law, has stated for marriage before the Law no 1/1974, could registered their marriage [26].

We had interviewed 12 women to tell their experiences of marriage from their side, the its bat is a practical gender need, probably an uninteresting for others. However, when they discussed their marriage they can tell that the women in the village at present understand to have their marriage certificate and they try not to marry their children under age. The process of itsbat becomes the event of the village, that they make a village celebration of it. It becomes a strategic gender need as the women now talk about their marriage and support their children to marriage properly. They also know the place of the office of the marriage registry, the process opens their horizon of having a legitimate and know the institution.

The women's movement is very cautious about it because they prevent the its bat as the way for the polygamous male to register their marriage. In religion the polygamy is not a necessity, it is like a safety valve institution if something happened to the marriage with the consent of both sides. However, in the law, the marriage system is monogamy. The women's movement argues that there is less social sanction toward polygamous males, instead of religions are used by the polygamous male. The women's movement states that child marriage as a social problem because the rate is still high. The other challenge situation is political awareness of marriage and women's issues. It is rather awkward that politics are focusing on these issues but less on the women's movement's arguments. It somehow reflects the sex/gender system in Indonesia and probably has some relation to the construction gender over Orders - from women as support in Orde Lama to the demise of women's movement but support women constructed issue in Orde Baru [27] [28]. This article would not discuss it, hoping for another opportunity.

Interreligious marriage is mostly problematic that they have to choose one religion, furthermore convert the religion becomes an issue. The other problem relates to the acknowledge religion are Islam, Christian, catholic, Hindu, Budha, and Khonghucu, this is a special case for the adat community who have traditions and their marriage ceremony. As a belief, there is a living verse that the Muslim has to marry other Muslims, especially women. Male is still possible to marry non-Muslims, but in general, the law has stated that marriage is legitimate to marry among people with similar religions. However, there are several cases of mixed marriage in celebrities such as Lydia Kandow with Jamal Mirdad, or Yuni Shara with Henry Siahaan. Some of the couples have their marriage registered in other countries and then registered through the office of the population in the district office.

Those who are not in the legitimate religion is having difficulty to get their marriage registered. This problem has started in the ' $80 \mathrm{~s}$, the discourse that interreligious marriage makes the Islamic community uneasy, due to consideration of the religion in one's family. The interreligious marriage would make people confused over religion and religious norms are difficult to be taught. This is about belief where people would strive to keep it [29].

The contract marriage happened in specific and become the destination to some of the Arab or claim to be Arab [30]. They visit for some months or even years and have a contract marriage some of them have offspring too. Somehow in the Tugu, Puncak, one will wonder that they have been traveling in Arab's country. There are restaurants, travel agents, laundry, goods from Arabs that are easily found along the road. This place has been a destination and contract marriage is a part of it, although local leaders refuse by saying it is just a 
case and it is detrimental to the society at large. They just use the name of the place but the doer living far away from this place. In reality, you can see the existent of the Arabs, some of them are with family, some of them even come and bring money to the community.

In the type of marriage, there is mut' $a h$, a Shia tradition, that man can marry a woman with respect and in a contract for the time of their consent [31] [32] [33]. If in the contract, one has offspring, therefore the male has to provide for them. It is not clear whether they are Shia or not, because of the unavailability of the registered dwellers or the marriage process. This is a sensitive issue, but it also reflects the ambiguity of the marriage for the good of society or male (Arab) preferences only. For women, it is subordination and the offspring would have difficulty in their civil rights, they are seen as economically powerless, and their function solely for sexuality.

\section{Conclusion}

There are three types of sharia definition, first, as formal or rasmiah, which discussed the problem in terms of law and the different systems that have been living such as national law and Islamic law, we still have adat Law. The discussion is about the legitimate authority in marriage, it is also supported by several institutions such as the office of marriage, office to population administration, the Religious Court. The second definition is the dzatiah or the substance, ideally speaking this is rahmatan lil alamin, that Islamic norms, value, and the rule should be for the welfare of all, not just for the Muslims. The third is the ruhiah or the essential where the law supports the Indonesia nation and its diversity.

The problem would be clearer by using a critical assessment of Urry about society. Is their society if we talk about sharia, the belief side is wider than the existing diversity in primordial attachment, such as religion. As an effect, the discussion forgets about the ideal rahmatan lil alamin in practice [34] [35] [36] [37]. We seldom ask about what is the meaning of sharia as an expression of the society that has history and similar experience for so long for a nation. The other thing taken from Urry's is his discussion about citizen, as a perspective, there is a substance from feminism that says women or women's problem has not seen as a problem, especially asking the meaning of citizen for women. As a citizen, some duties and rights go together, in the belief side of sharia is only the duties but seldom about the rights. That the sharia has problematic relations with the international relation of international law, how the sharia would deal with the other interest [38]. Without putting international relations as an important element, the sharia would be seen only reflect the interest of Islamic countries or the place where there are significant numbers of Muslims such as Indonesia.

\section{References}

[1] M. Hisyam, Dinamika Pelaksanaan Syariat Islam di Indonesia, Tinjauan Sejarah, Jakarta, LIPI Press. Jakarta: LIPI Press, 2012.

[2] J. 'Athiyah, "Al-Nadhriyyat al-'Ammah li Syari'ai al-Islamiyyah, Mathba'ah alMadinah."

[3] P. L. Berger and T. Luckman, Social Construction of Reality. London: Penguin Book.

[4] M. Khadduri, Teologi Keadilan: Perspektif Islam. Surabaya: Risalah Gusti, 1999.

[5] N. Madjid, Tradisi Islam. Jakarta: Paramadina, 1997.

[6] M. Mahin, "Kaharingan, Dinamika Agama Dayak di Kalimantan Tengah," Universitas Indonesia, 2009.

[7] A. M. Buttenheim and N. Jenna, "Ethnic Diversity, Traditional Norms, and Marriage Behaviour in Indonesia, dalam," Popul. Stud. (NY)., vol. 63, no. 3, 2009.

[8] Santoso., Widjajanti M, S. Nurhasanah, and K. Tridewiyanti, Eds., Dinamika Pelaksanaan Syariah, Kelembagaan Ekonomi Syariah dan Pengadilan Agama. Jakarta: Yayasan Pustaka Obor Indonesia, 2020.

[9] M. Abdurrachman, Islam Transformatif, Jakarta, PustakaFirdaus. Jakarta: Pustaka Firdaus, 1995.

[10] J. Urry, Sociology Beyond Societies. 2012.

[11] R. S. Cavan, "Concepts and Terminology in Interreligious Marriage," J. Sci. Study Relig., vol. 9, no. 4, 1979. 
[12] I. Masduqi, "Nikah Sirri Dan Istbat Nikah Dalam Pandangan Lembaga Bahtsul Masail Pwnu Yogyakarta," Musãwa J. Stud. Gend. dan Islam, vol. 12, no. 2, p. 187, 2013, doi: 10.14421/musawa.2013.122.187-200.

[13] A. Appadurai, "Disjuncture and Difference in the Global Cultural Economy," Public Cult., vol. 2, no. 2, pp. 1-24, Apr. 1990, doi: 10.1215/08992363-2-2-1.

[14] van W. K. Stuart, "Women's Bid for Equality in the United States in an Era of Backlash: Two Steps Forward and One Step Back," Open Soc. Sci. J., vol. 1, pp. 15-21, 2008.

[15] van Wormer Katherine, "Anti-Feminist Backlash and Violence against Women Worldwide," Soc. Work Soc., vol. 6, no. 2, 2008.

[16] N. Nurmila, Women, islam and everyday life: Renegotiating polygamy in Indonesia. 2009.

[17] BPS, "Jumlah Perceraian, data dari Dirjen Badan Peradilan Agama per 4 Maret 2019," 2019.

[18] Usman, H. M, W. M. Santoso, E. Turmudi, and D. Purwoko, Dinamika Pelaksanaan Syariah: Perkawinan dalam Kontestasi Agama dan Negara. LIPI Press, 2020.

[19] Bafadhal Faizah, "Itsbat Nikah dan Implikasinya terhadap Status Perkawinan Menurut Peraturan Undang Undang," J. Ilmu Huk., 2014.

[20] S. Blackburn and S. Bessell, "Marriageable Age: Political Debates On Early Marriage In Twentieth- Century Indonesia," Indonesia, no. 63, pp. 107$141,1997$.

[21] Kustini and N. Rofiah, "Perkawinan Tidak Tercatat, Pudarnya Hak Hak Perempuan (Studi di Kabupaten Cianjur)," Harmoni, vol. 12, no. 2, 2013.

[22] A. G. Nashori, Peradilan Agama di Indonesia Pasca UU No. 3 Tahun 2006, Sejarah, Kedudukan \& Kewenangan, Yogyakarta. Yogyakarta: UII Press, 2011.

[23] M. K. Yakin, "Ratio Decidendi Penetapan Pengesahan (Itsbat) Nikah Di Pengadilan Agama," Yuridika, vol. 30, no. 2, p. 254, 2017, doi: 10.20473/ydk.v30i2.4655.

[24] W. M. Santoso, "Itsbat Nikah bagi
Perlindungan Perempuan," in pertemuan Dharma Wanita LIPI pada 19 Mei 2015, di Widyagraha lt 1., 2015.

[25] R. Ida, I. Muzaiyyanah, and D. Fajriyah, "Menebar Upaya Mengakhiri Kelanggengan: Problematika Perkawinan Anak di Nusa Tenggara Barat," Harmoni, vol. 12, no. 2, 2013.

[26] Y. Muthmainnah, "Perempuan dalam Budaya Pernikahan di Indonesia, Membaca Ulang RUU Hukum Materil Peradilan Agama Bidang Pernikahan," 2010. .

[27] W. M. Santoso, "Perempuan dalam Kebijakan; lemahnya Representasi Perempuan," in Konferensi Nasional Sosiologi III. Transformasi Demokrasi Indonesia Menuju Perubahan yang Bermakna. Yogjakarta, 20-22 Mei 2014., 2014.

[28] A. S. Wharton, The Sociology of Gender, An Introduction to Theory and Research. Malden: Blackwell Publishing, 2005.

[29] M. Karsayuda, Perkawinan Beda Agama, Menakar Nilai-Nilai Keadilan Kompilasi Hukum Islam,. Yogyakarta: Total Media, 2006.

[30] Suhanah and Fauziah, "Kawin Kontrak di Kawasan Puncak Kabupaten Bogor," Harmoni, 2011.

[31] Syehabudin, Alvian, "Fenomena Nikah Mu'ah di Wilayah Puncak Kabuipaten Bogor, Jawa Barat Dalam Perspektif Undang-Undang Perkawinan,” 2015.

[32] Tim Pengkaji Baintelkam Mabes Polri, "Kajian Intelegen Strategis tentang Konflik Syiah-Sunni di Indonesia," 2016.

[33] Trisnanto. Ronny Hidroson, "Kawin Mu'tah Ditinjau Dari Undang -Undang Nomor 1 Tahun 1974 dan Peraturan Pelaksanaannya. Kompilasi Hukum Islam, Hukum Perkawinan Sunni, Hukum Perkawinan Syiah, Beserta AkibatAkibatnya Jika Tetap Dilaksanakan.”

[34] A. Wahid, Islam Kosmopolitan, NilaiNilai Indonesia danTranformasi Kebudayaan. Jakarta: The Wahid Institute, 2006.

[35] A. Rahmawati, "Faith, fashion and femininity: visual and audience analysis of indonesian muslim fashion blogs," PQDT - UK Irel., no. September, 2016. 
[36] Verter Bradford, "Spiritual Capital: Theorizing Religion with Bourdieu Against Bourdieu," Sociol. Theory, vol. 21, no. 2, 2003.

[37] P. Bourdieu, Outline of a Theory of Practice. Cambridge: Cambridge University Press, 1977.

[38] A. A. An-na, Islam and the Negotiating the Future of Sharia. Cambridge: Harvard University Press, 2008. 